\title{
ДОСЛІДЖЕННЯ МЕТОДІВ СПЕКТРАЛЬНОГО АНАЛІЗУ ЗОБРАЖЕНЬ ДЛЯ ДЕТЕКТУВАННЯ ЛІСОВИХ ПОЖЕЖ 3 ВИКОРИСТАННЯМ ТЕХНОЛОГІЙ ОБЧИСЛЮВАЛЬНОГО ІНТЕЛЕКТУ
}

У статті проведено дослідження методів спектрального аналізу зображень для детектування лісових пожеж з використанням технологій обчислювального інтелекту. Для проведення спектрального аналізу були використані супутникові знімки лісових пожеж з відкритого джерела NASA Earth Observatory, яка є основним джерелом супутникових зображень та іншої наукової інформації, щзо стосується клімату $і$ навколишнього середовища, що надаються National Aeronautics and Space Administration для проведення широкого кола досліджень.

Для створення трьохвимірної моделі вогню було використано інструмент Volume Segmenter пакету MATLAB, за допомогою якого було виділено трьохвимірну зону вогню.

За допомогою інструменту Color Thresholder пакету MATLAB було сегментовано кольорове зображення вогню, встановлено порогові значення для колірних каналів на основі різних колірних просторів та створено бінарну маску сегментачії для кольорового зображення.

Для створення нейронної мережі, щзо призначена для аналізу зображення розповсюдження вогню було використано метод спряжених градієнтів. Цей метод було обрано тому, щзо він не потребує багато системної пам'яті, а також надає можливість структурувати будь-які дані, постійно покращуючи свої властивості. Для навчання моделі було здійснено кілька проходів, щоб нейронна мережа показала максимально точні результати.

Результати дослідження будуть використані для формування веб-сервісу у режимі реального часу, який буде фіксувати небезпечні природні явища, формувати сповіщення та надавати рекомендації для оперативної ліквідації їх наслідків.

Ключові слова: спектральний аналіз зображень, супутникові знімки лісових пожеж, метод спряжених градієнтів, нейронні мережі, маска сегментації кольорового зображення.

Н.В. ГОЛОВИНА

Херсонский национальный технический университет ORCID: 0000-0003-0985-0135

Е.Н. ЛЯШЕНКО

Херсонский национальный технический университет ORCID: 0000-0002-5429-8389

\section{ИССЛЕДОВАНИЕ МЕТОДОВ СПЕКТРАЛЬНОГО АНАЛИЗА ИЗОБРАЖЕНИЙ ДЛЯ ДЕТЕКТИРОВАНИЯ ЛЕСНЫХ ПОЖАРОВ С ИСПОЛЬЗОВАНИЕМ ТЕХНОЛОГИЙ ВЫЧИСЛИТЕЛЬНОГО ИНТЕЛЛЕКТА}

В статье проведено исследование методов спектрального анализа изображений для обнаружения лесных пожаров с использованием технологий вычислительного интеллекта. Для проведения спектрального анализа были использованы спутниковые снимки лесных пожаров из открытого источника NASA Earth Observatory, который является основным источником спутниковых изображений и другой научной информащии, касающейся климата и окружающей средь, предоставляемой National Aeronautics and Space Administration для проведения широкого круга исследований.

Для создания трехмерной модели огня был использован инструмент Volume Segmenter naкета MATLAB, с помощью которого была выделена трехмерная зона огня.

C помощью инструмента Color Thresholder пакета MATLAB было сегментировано иветное изображение огня, установлены пороговые значения для иветовых каналов на основе различных цветовых пространств и создана бинарная маска сегментации для иветного изображения.

Для создания нейронной сети, предназначенной для анализа изображения распространения огня, был использован метод сопряженных градиентов. Этот метод был выбран потому, что он не требует 
много системной памяти, а также предоставляет возможность структурировать любые данные, постоянно улучшая свои свойства. Для обучения модели было сделано несколько проходов, чтобы нейронная сеть показала максимально точные результаты.

Результаты исследования будут использованы для создания веб-сервиса в режиме реального времени, который будет фиксировать опасные природные явления, формировать уведомления и давать рекомендации для оперативной ликвидации их последствий.

Ключевые слова: спектральный анализ изображений, спутниковые снимки лесных пожаров, метод сопряженных градиентов, нейронные сети, маска сегментации ияветного изображения.

N.V. HOLOVINA

Kherson National Technical University ORCID: 0000-0003-0985-0135

O.M. LIASHENKO

Kherson National Technical University ORCID: 0000-0002-5429-8389

\section{RESEARCH OF SPECTRAL IMAGE ANALYSIS METHODS FOR DETECTING FOREST FIRES USING COMPUTER INTELLIGENT TECHNOLOGIES}

The article studies the methods of spectral analysis of images for detecting forest fires using computer intelligence technologies. For spectral analysis, satellite images of wildfires from the open source NASA Earth Observatory were used, which is the main source of satellite images and other scientific information related to climate and the environment provided by the National Aeronautics and Space Administration for a wide range of research.

The Volume Segmenter tool of the MATLAB package was used to create a three-dimensional model of the fire, with the help of which a three-dimensional zone of fire was selected.

The color image of the fire was segmented, threshold values for color channels were set based on different color spaces, and a binary segmentation mask was created for the color image, using the MATLAB Color Thresholder tool.

The conjugate gradient method was used to create a neural network for analyzing the image of the spread of fire. This method was chosen because it does not require a lot of system memory, and also provides the ability to structure any data, constantly improving its properties. To train the model, several passes were carried out so that the neural network showed the most accurate results.

The results of the study will be used to create a web service in real time, which will record hazardous natural phenomena, generate notifications and make recommendations for the prompt elimination of their consequences.

Key words: spectral analysis of images, satellite images of forest fires, conjugate gradient method, neural networks, color image segmentation mask.

\section{Постановка проблеми}

Аналіз розвитку природних катастрофічних явищ у всьому світі показує, що, незважаючи на науково-технічний прогрес, захищеність людей і техносфери від природних небезпек не збільшується. Кількість жертв від руйнівних природних явищ, до яких можна віднести лісові пожежі в останні роки щорічно збільшується.

У даний час існує багато досліджень з приводу того, що природні катастрофи є глобальною проблемою і одним 3 найважливіших факторів сталого розвитку економіки. При цьому не існує універсального рішення, яке було б направлене на підвищення точності прогнозування природних катастроф з метою їх зменшення та попередження.

Таким чином, актуальною науково-прикладною проблемою $є$ розроблення методів аналізу зображень для детектування природних катастроф 3 використанням технологій обчислювального інтелекту з метою їх запобігання та збереження життя людей, а також економічних та інших структур.

Аналіз останніх досліджень і публікацій

Питаннями аналізу зображень для детектування природних катастроф 3 використанням технологій обчислювального інтелекту з метою іх запобігання та збереження життя людей займається автор роботи [2]. У цій роботі вводиться суттєво новий підхід «розробки за допомогою моделювання» для створення та впровадження алгоритму виявлення пожежі за допомогою TMS320DM642 DSP та MATLAB/Simulink. Модель алгоритму виявлення пожежі побудована в Simulink у вигляді графічних блоків. Код C автоматично генерується з блок-діаграм за допомогою Майстерні реального часу (RTW). Виконуваний файл, створений з коду C через с-компілятор TI DSP, завантажується на цільову плату DSP i реалізується через DSP. Ця методологія проектування відкриває більш легкий шлях для реалізації складного алгоритму високого рівня в цифровому сигнальному процесорі (DSP). Експериментальні 
результати показують, що запропонований підхід не тільки має хороші показники виявлення, але й ефективно спрощує процес розробки.

У роботі [3] автор розглядає алгоритм виявлення пожежі на основі комп’ютерного зору. Запропонований алгоритм виявлення пожежі складається з двох основних частин: моделювання кольору вогню і виявлення напрямку його руху. Алгоритм можна використовувати паралельно зі звичайними системами виявлення пожежі для зменшення ризиків помилкового виявлення тривоги. Його також можна розгортати як автономну систему виявлення пожежі за допомогою спеціальних датчиків через пристрій збору відео. Запропонована модель кольору вогню перевірена 3 десятьма різноманітними послідовностями, включаючи різні типи вогню. Експериментальні результати досить обнадійливі 3 точки зору правильної класифікації пікселів вогню за кольором.

У роботі [6] наведено методи геоінформаційного моніторингу. Геоінформаційний моніторинг застосовують для спостереження і гасіння лісових пожеж. У роботі також наведено опис космічного моніторингу, який є складовою частиною геоінформаційного моніторингу. У роботі наведено опис спеціалізованої інформаційної системи моніторингу пожеж. Спеціалізована інформаційна система моніторингу пожеж (СІСМП) забезпечує збір, зберігання, обробку і поширення геоданих про пожежі в лісах, умовах виникнення і розвитку лісових пожеж, рівні їх впливу на навколишнє середовище, одержуваних на основі наземних, повітряних і космічних засобів і методів спостереження за лісовими пожежами і погодними умовами. Масштаб технічної реалізації цієї системи може бути від окремої ГІС до ситуаційного центру. Інформаційна підтримка системи здійснюється на порталі. Інформація представлена у вигляді сукупності таблиць, електронних тематичних карт і результатів обробки супутникових зображень, які оперативно оновлюються на сервері в режимі реального часу.

\section{Формулювання мети дослідження}

Цю статтю спрямовано на дослідження методів аналізу зображень для детектування природних катастроф з використанням технологій обчислювального інтелекту з метою їх запобігання та збереження життя людей, а також економічних та інших структур.

\section{Викладення основного матеріалу дослідження}

Для проведення спектрального аналізу були використані супутникові знімки лісових пожеж 3 відкритих джерел NASA Earth Observatory [1] (рис.1).

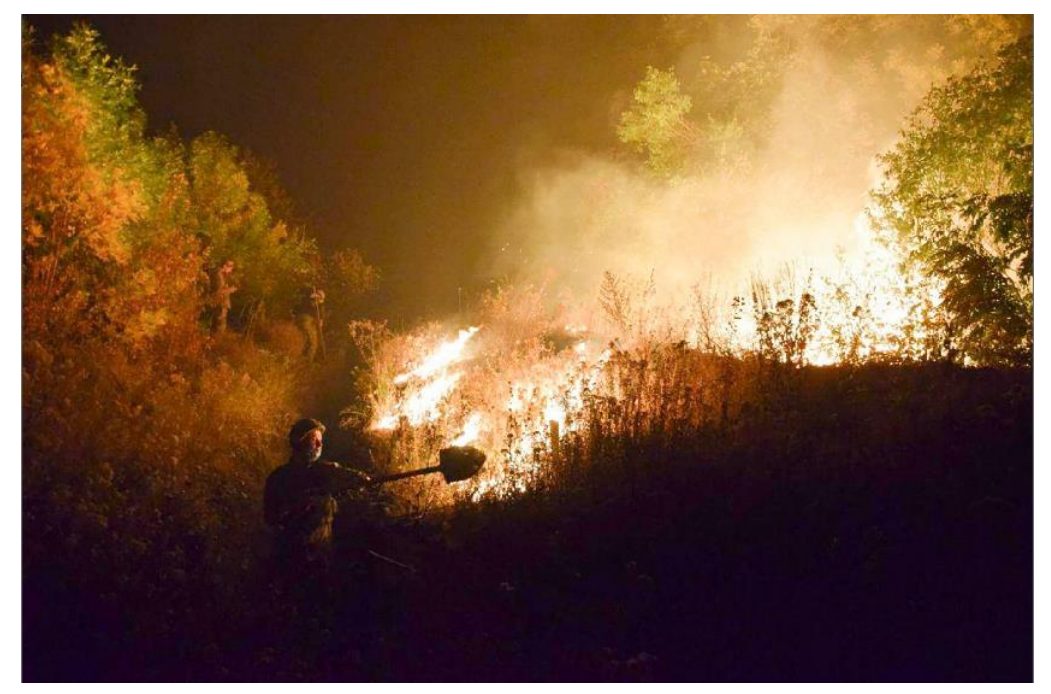

Рис. 1. Знімок лісової пожежі з відкритих джерел NASA Earth Observatory

Опис вогню було здійснено за допомогою параметрів RGB, HSV, YCbCr, L*a*b*. Для аналізу супутникових знімків було використано спектр між жовтим та червоними кольорами. Це означає, що коли колір вогню стає близьким до червоного і виділяє характерне світіння, можна використати цю властивість для його виявлення [4].

Сигнали $\mathrm{YCbCr}$ було отримано за рахунок обчислень гама-налаштованого зображення у форматі RGB за допомогою виділених констант $\mathrm{K}_{\mathrm{R}}, \mathrm{K}_{\mathrm{G}}, \mathrm{K}_{\mathrm{B}}$ таким чином [5]:

$$
\begin{gathered}
Y^{\prime}=K_{R} * R^{\prime}+K_{G} * G^{\prime}+K_{B} * B^{\prime}, \\
P_{B}=\frac{1}{2} * \frac{B^{\prime}-Y^{\prime}}{1-K_{B}}
\end{gathered}
$$




$$
P_{R}=\frac{1}{2} * \frac{R^{\prime}-Y^{\prime}}{1-K_{R}}
$$

У рівнянні (1) коефіцієнти $K_{R}, K_{G}$ та $K_{B}$ визначають простір RGB, де важливою характеристикою $\epsilon$ таке рівняння [5]:

$$
K_{R}+K_{G}+K_{B}=1 .
$$

Рівняння (4) виділяе кольорову матрицю за розрахунками. В рівнянні (4) також використовуються символи гама-корекції. Це означає, що значення $R^{\prime}, G^{\prime}, B^{\prime}$ номінально знаходяться в діапазоні дії від 0 до 1 . При цьому 0 означає мінімальну інтенсивність зображення, а 1 - максимально можливе значення яскравості. Також значення кольорового відображення вогню може мати значення від $-0,5$ до $+0,5$ в залежності від номінального значення. Зворотній процес перетворення також може бути легко отриманий за рахунок інвертування дійсного відображення. Перетворення відбувається за рахунок використання констант, що надає можливість отримати потрібний результат при обчисленнях (рис. 3-7).

На рис. 2 представлений графік вихідного зображення.

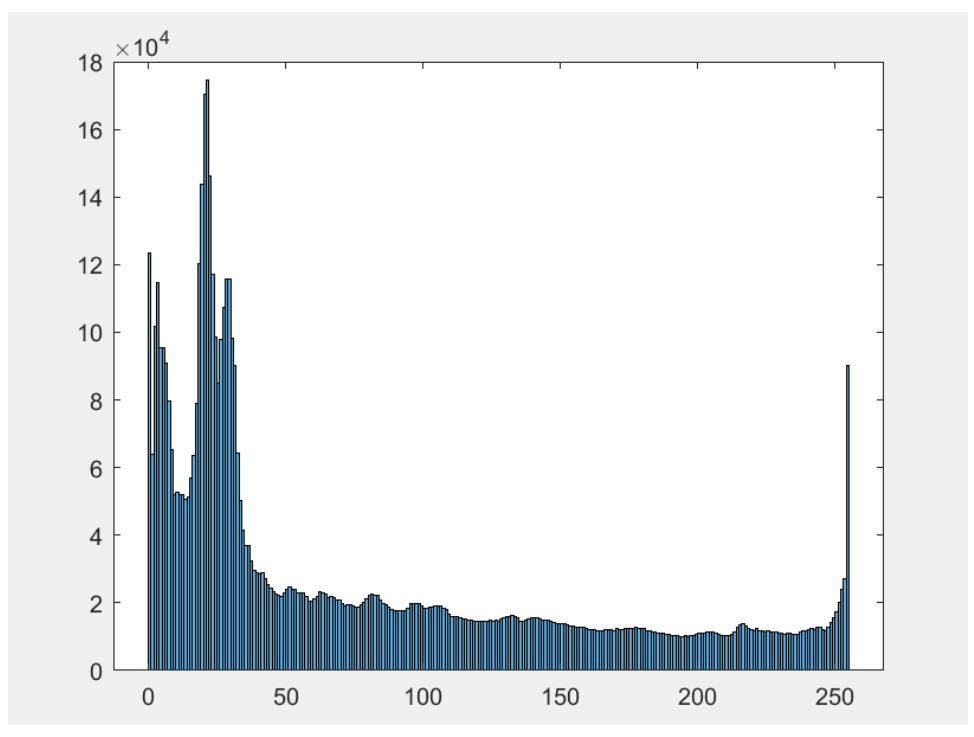

Рис. 2. Графік вихідного зображення

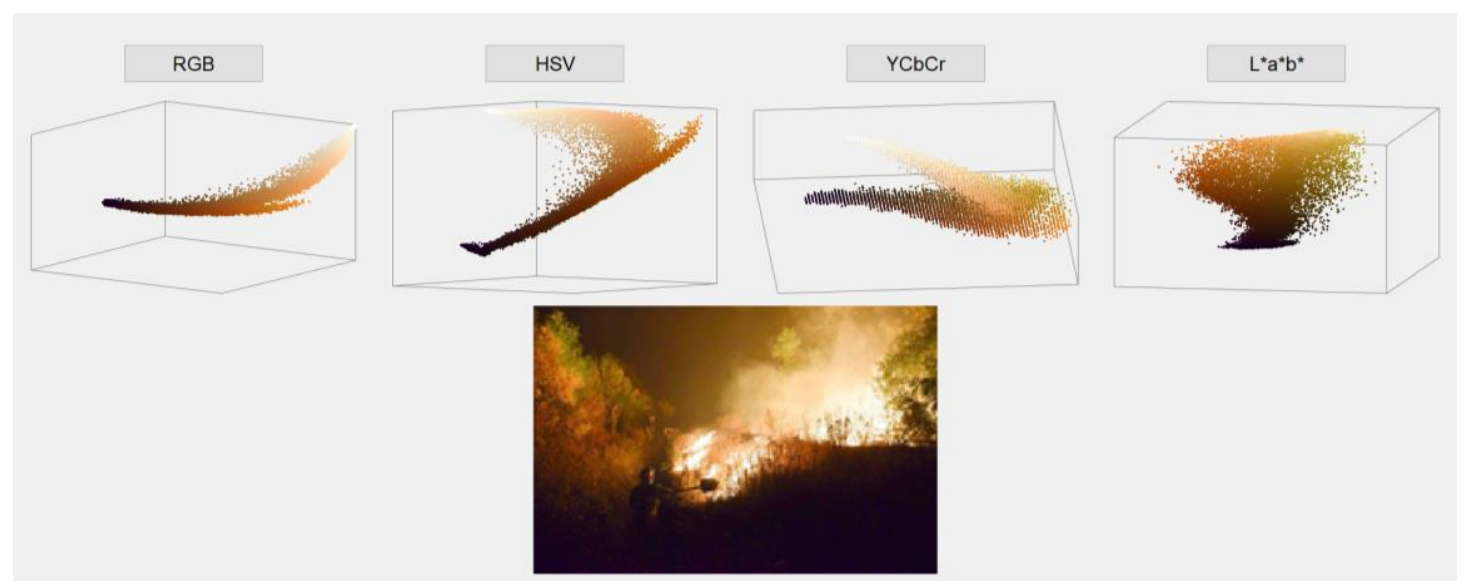

Рис. 3. Колірні маски для відображення спектру вогню 

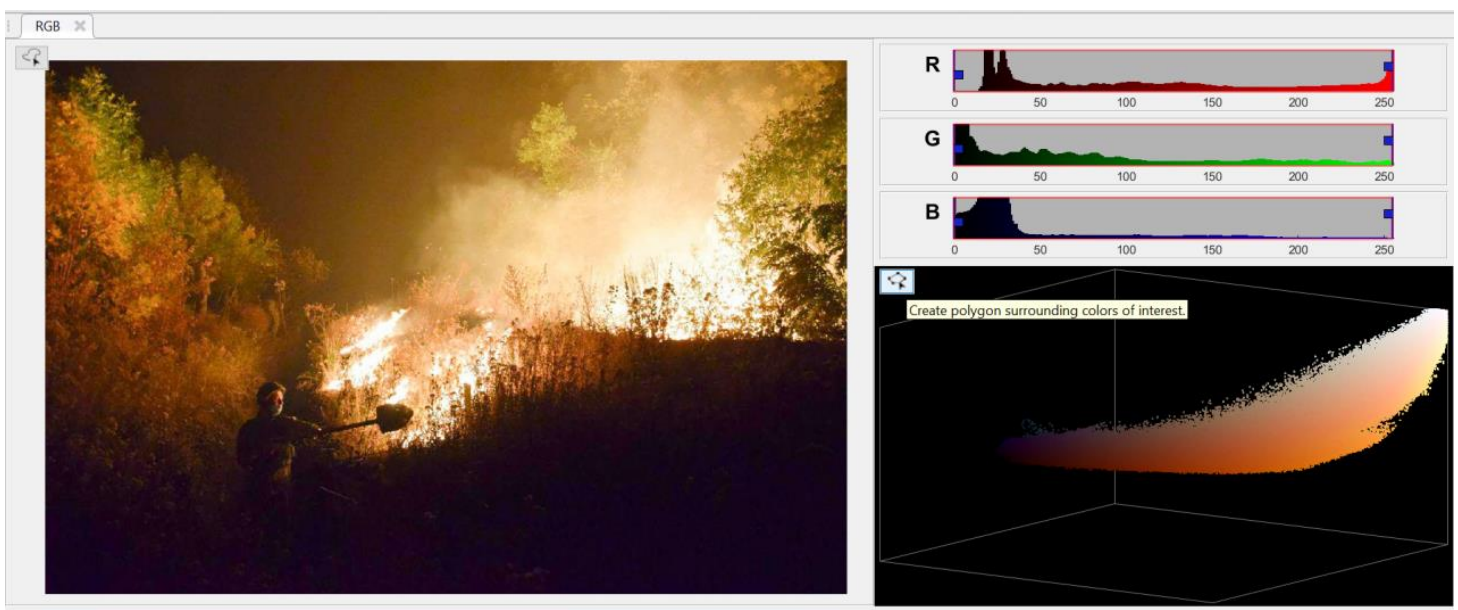

Рис. 4. Зображення вогню в спектрі RGB

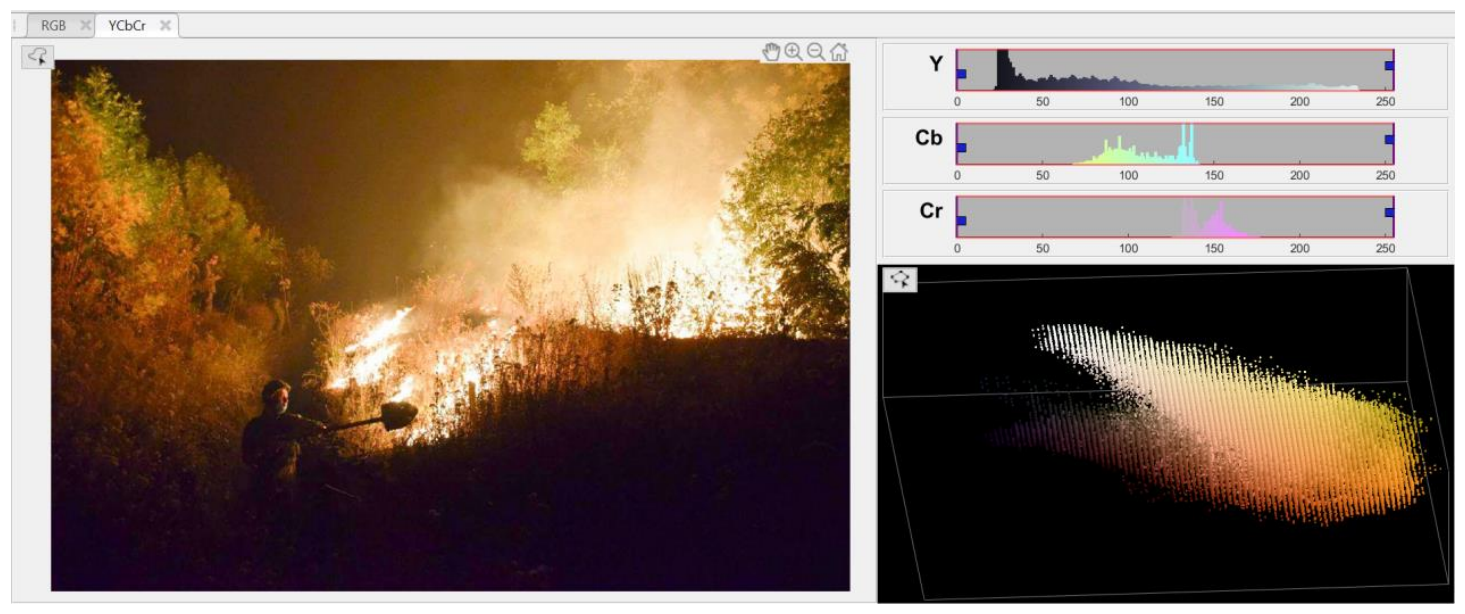

Рис. 5. Зображення вогню в спектрі YCbCr

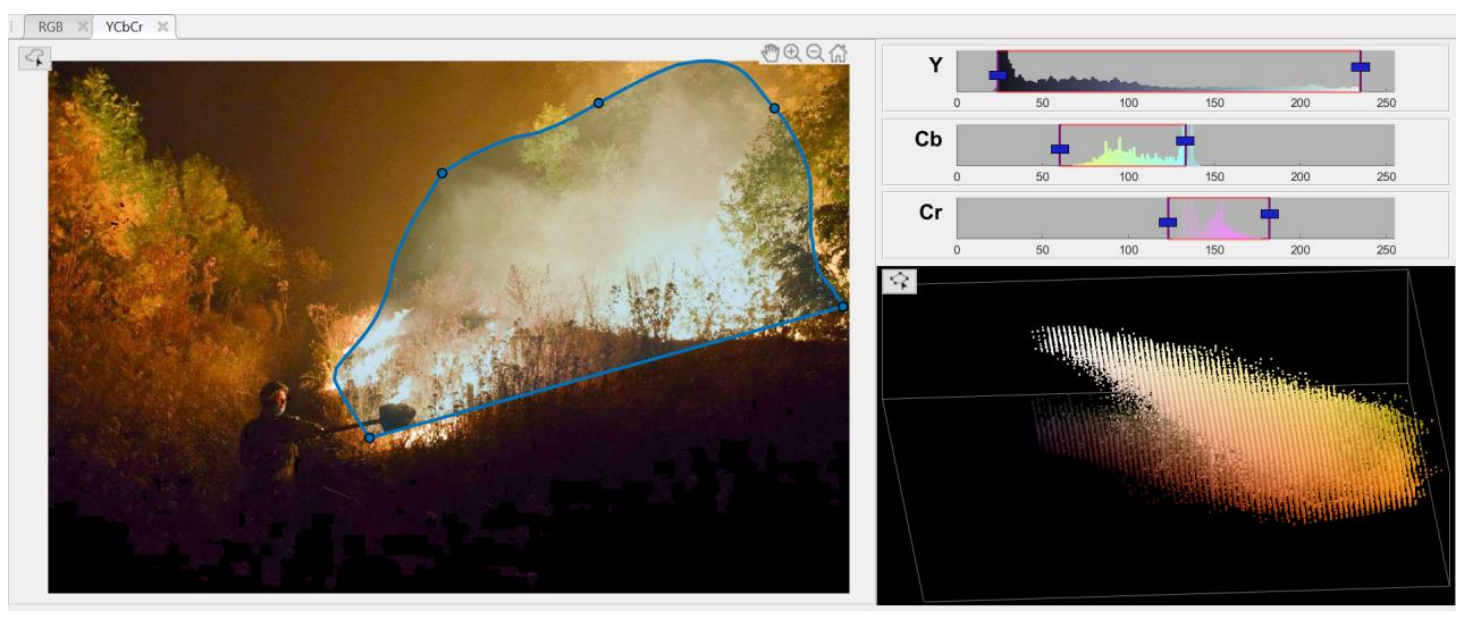

Рис. 6. Виділення зон активного вогню на зображенні 


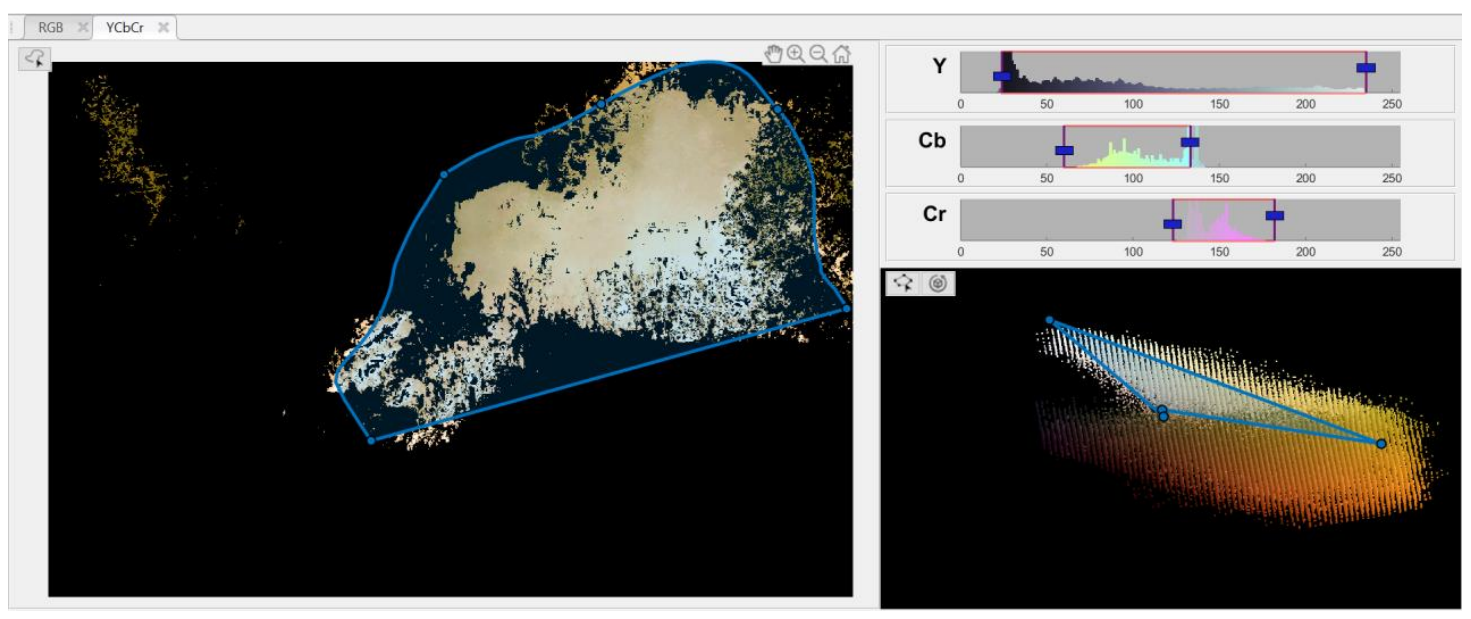

Рис. 7. Звуження дії спектру вогню

\section{Створення трьохвимірної моделі.}

Для створення трьохвимірної моделі було використано інструмент Volume Segmenter в MATLAB. За допомогою даного інструменту було виділено трьохвимірну зону вогню на зображенні, що аналізується (рис. 8-10).
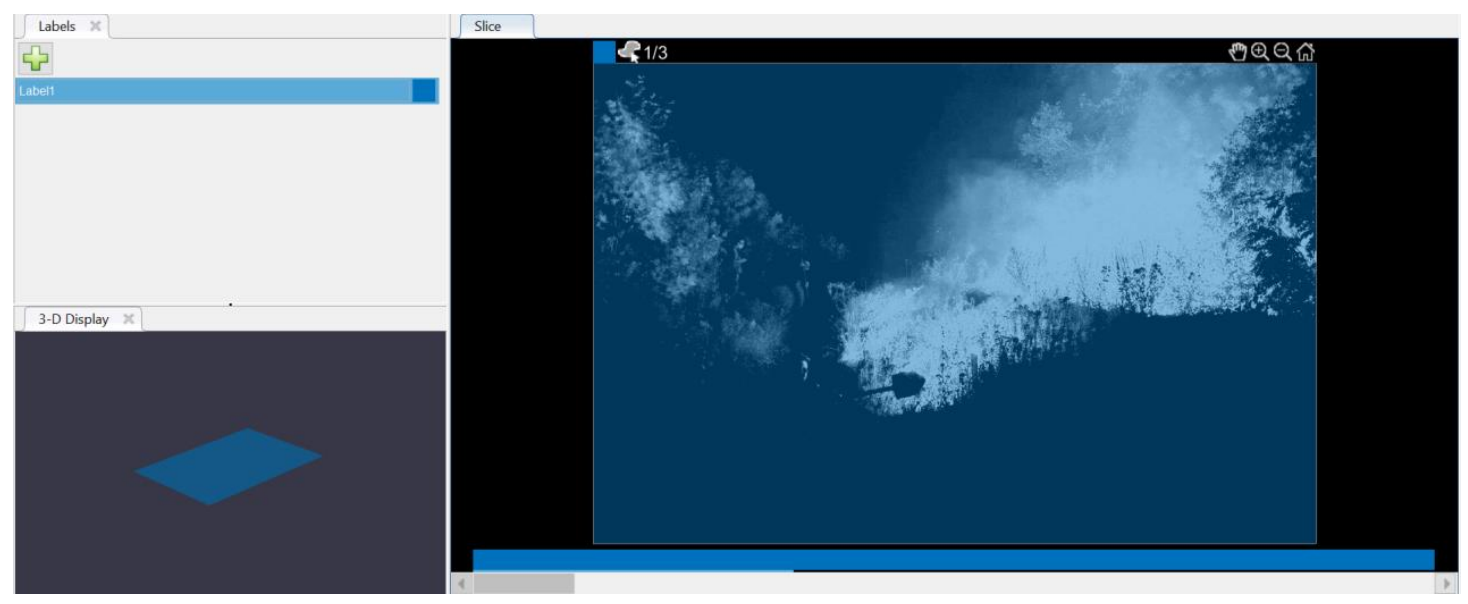

Рис. 8. Сегмент 1

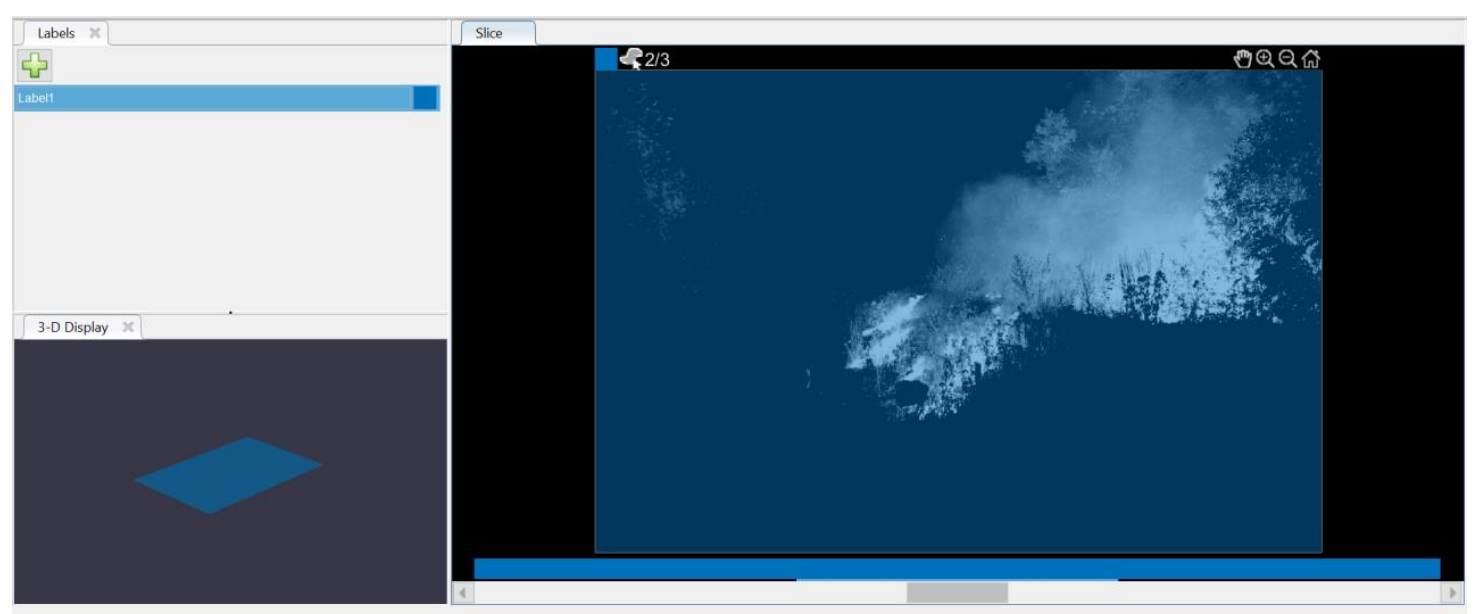

Рис. 9. Сегмент 2 


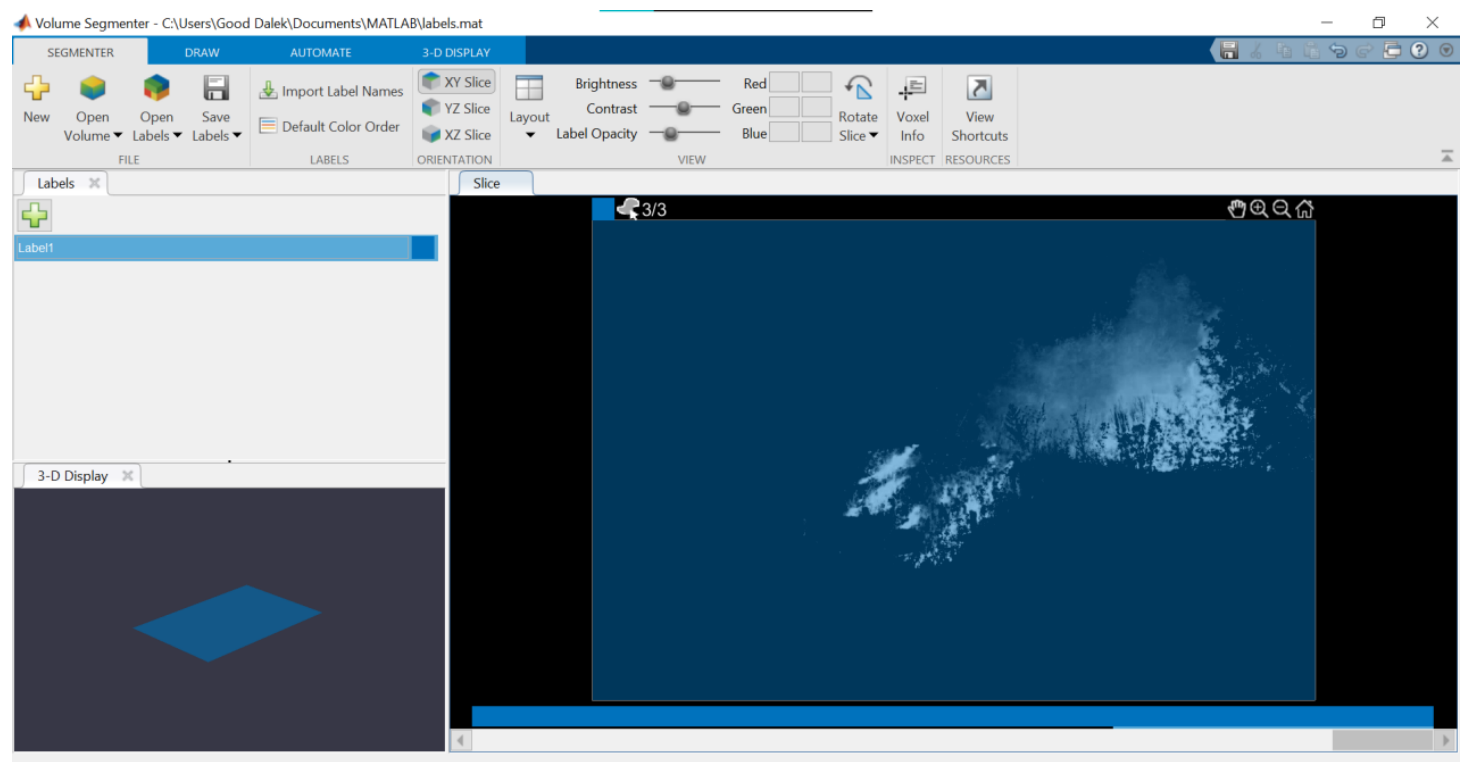

Рис. 10. Сегмент 3

\section{Бінарна маска сегментацї̈.}

За допомогою інструменту Color Thresholder було сегментовано кольорове зображення вогню, встановлюючи порогові значення для колірних каналів на основі різних колірних просторів. За допомогою цього методу було створено бінарну маску сегментації для кольорового зображення.

Поріг кольору підтримує сегментацію в чотирьох колірних просторах. У кожному колірному просторі відображаються зображення, три кольорові канали та значення кольору всіх пікселів як точки на тривимірному графіку колірного простору. Було обрано кольори, що включені до маски (рис. 11).

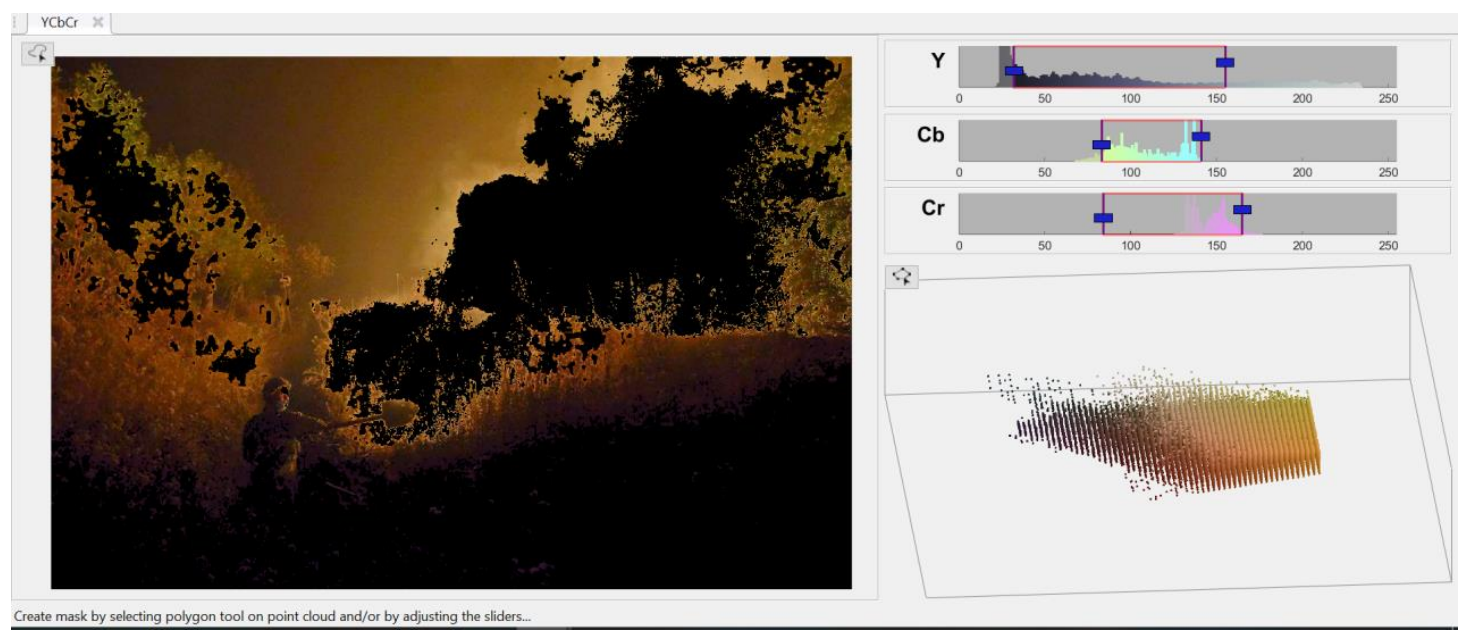

Рис. 11. Створення маски та виділення окремої зони вогню на зображенні

\section{Створення нейронної мережі.}

Для створення нейронної мережі, що призначена аналізу зображення розповсюдження вогню було використано метод спряжених градієнтів (Scaled Conjugate Gradient). Цей метод було обрано тому, що він не потребує багато системної пам'яті, а також надає можливість структурувати будь-які дані, постійно покращуючи свої властивості. Для навчання моделі було здійснено кілька проходів, щоб нейронна мережа показала максимально точні результати. Метод спряжених градієнтів часто реалізовується як ітераційний алгоритм, що застосовується до розріджених систем, які занадто великі, щоб обробляти їх шляхом прямої реалізації або інших прямих методів, таких як декомпозиція Холеського. Великі розріджені системи часто виникають при чисельному розв'язанні часткових диференціальних рівнянь або задачах оптимізації [7].

SCG-алгоритм не виконує пошук по лінії на кожній ітерації на відміну від інших алгоритмів спряженого градієнта, які вимагають пошук на кожній ітерації. SCG дозволяє уникнути важких операцій. 
Функція мережевого навчання даного алгоритму оновлює вагу та значення зміщення за методом масштабованого спряженого градієнта. Він може тренувати будь-яку мережу, доки її вага, чисті вхідні та передавальні функції мають похідні функцій. В алгоритмі SCG розмір кроку є функцією квадратичного наближення функції помилки, що робить їі більш надійною і незалежною від користувача 3 визначеними параметрами.

Розмір кроку оцінюється за допомогою іншого підходу. Крок другого порядку обчислюється таким чином [5]:

$$
\bar{s}_{k}=\frac{E^{\prime}\left(\bar{\omega}_{k}+\sigma_{k} \bar{p}_{k}\right)-E^{\prime}\left(\bar{\omega}_{k}\right)}{\sigma_{k}}+\lambda_{k} \bar{p}_{k},
$$

де $\lambda_{k}-$ це скалярна величина, яка 3 кожним кроком збільшується.

Розмір одного кроку розраховується за такою формулою:

$$
\propto_{k}=\frac{\mu_{k}}{\delta_{k}}=\frac{-\bar{p}_{j}^{T} E^{\prime}{ }_{q \omega}\left(\bar{y}_{1}\right)}{\bar{p}_{j}^{T} E^{\prime \prime}(\bar{\omega}) \bar{p}_{j}},
$$

де $\bar{\omega}$ - це ваговий коефіцієнт у просторі, $E^{\prime}\left(\bar{\omega}_{k}\right)$ позначає градієнт помилки, $E_{q \omega}^{\prime}\left(\bar{y}_{1}\right) \epsilon$ позначенням квадратичного наближення функції помилки, $\bar{p}_{j}$ позначає набір ненульових вагових векторів. $\lambda_{k}$ оновлюється з кожним кроком за формулою [5]:

$$
\bar{\lambda}_{k}=2\left(\lambda_{k}-\frac{\delta_{k}}{\left|\bar{p}_{k}\right|^{2}}\right) \text {. }
$$

Навчання припиняється, коли виникає будь-яка $з$ таких умов:

1) досягнуто максимальної кількості епох;

2) перевищено максимальний час;

3) досягнуто необхідного результату;

4) градієнт продуктивності падає нижче мінімального значення; ітерації;

5) показник перевірки збільшився більше, ніж максимальний час помилок з моменту останньої

6) час його зменшення (при використанні перевірки).

Результати представлені на рис. 12-16.

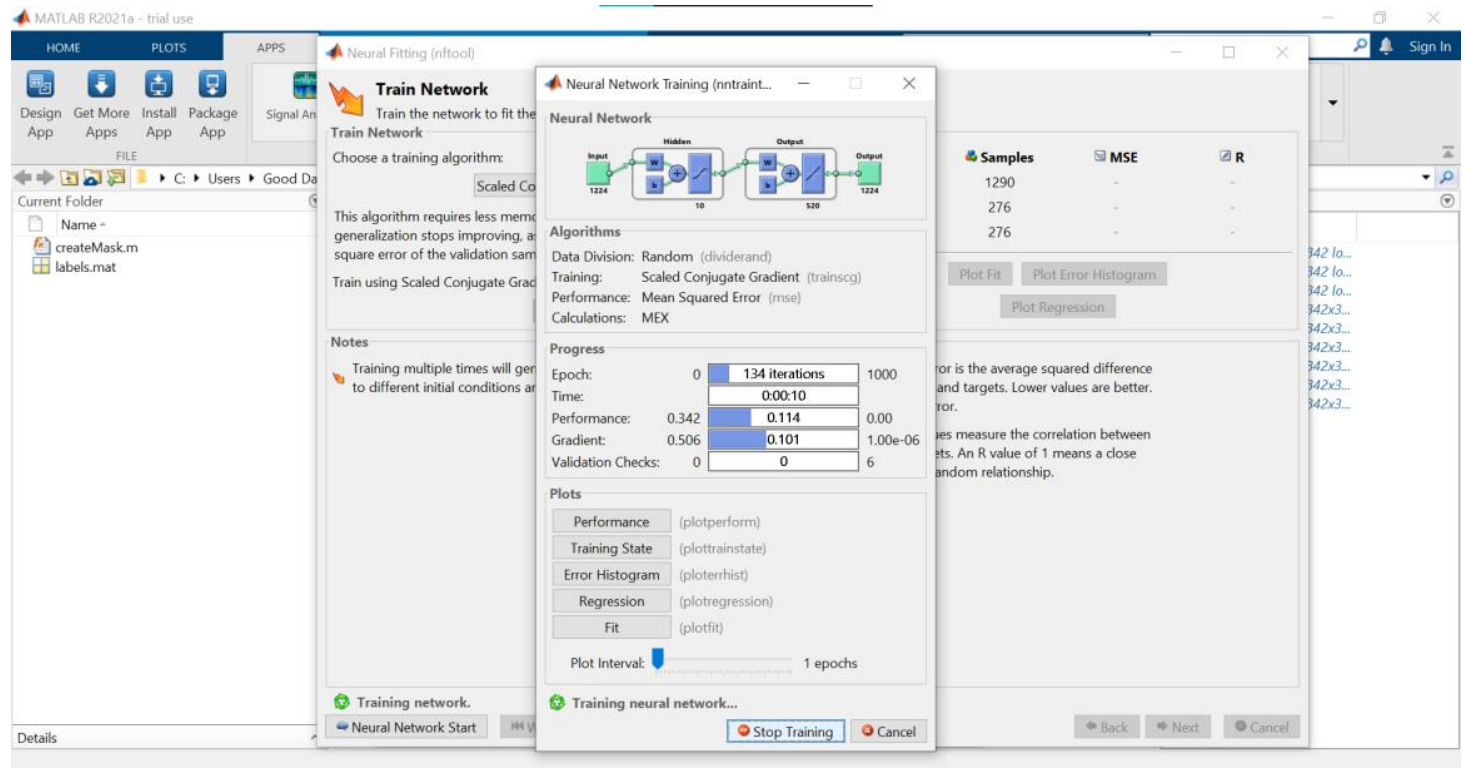

Рис. 12. Алгоритм навчання нейронної мережі 


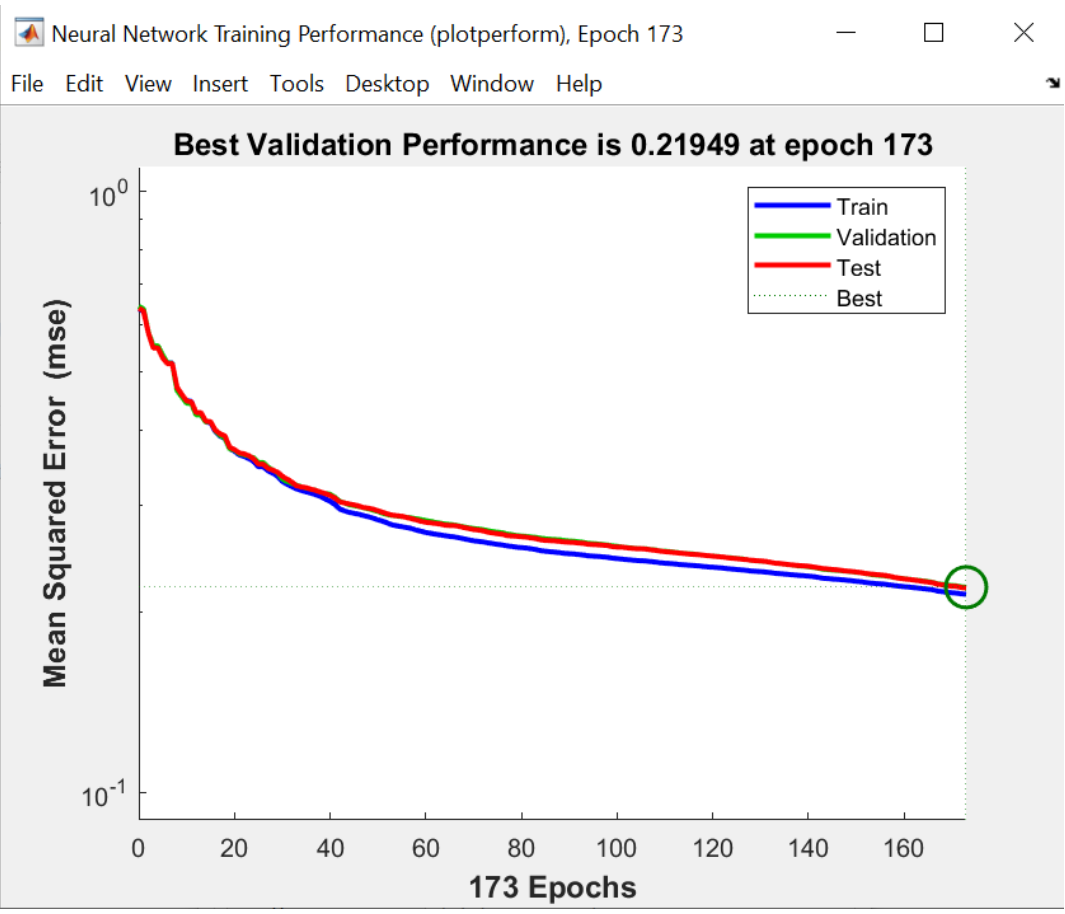

Рис. 13. Графік виконання алгоритму навчання

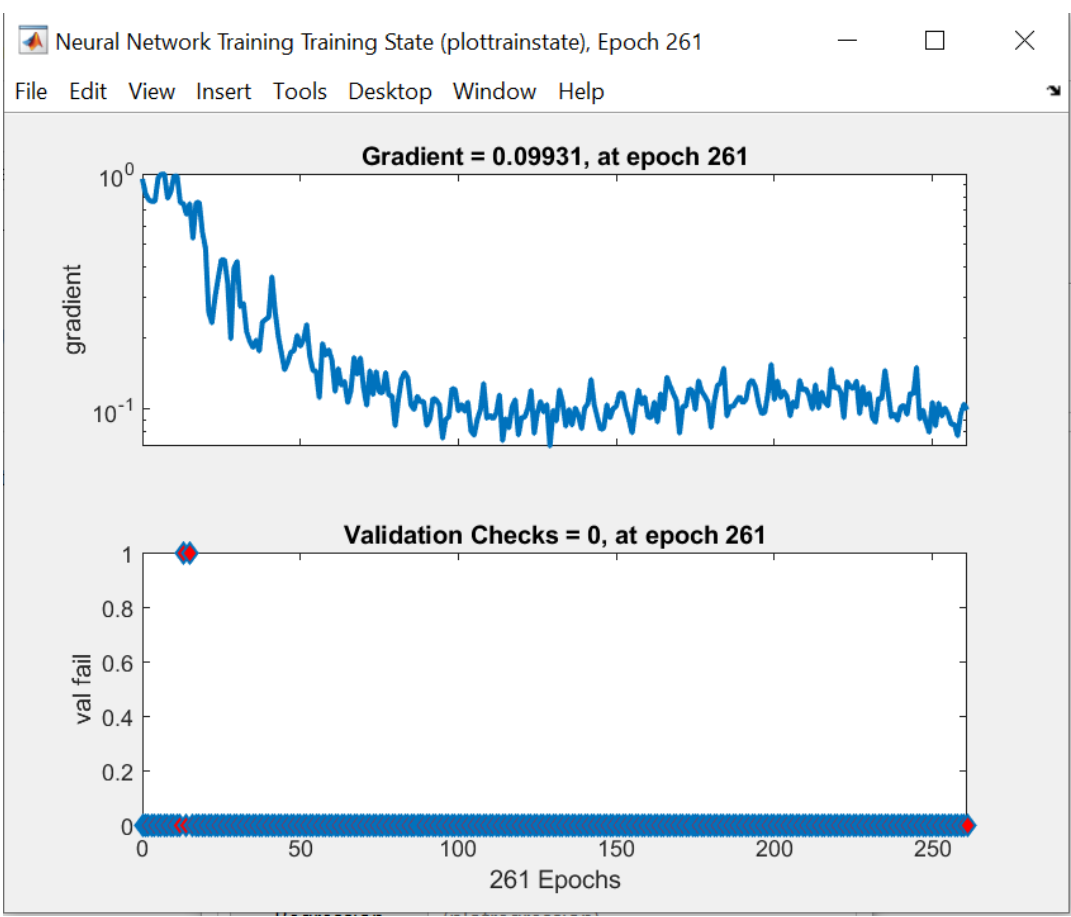

Рис.14. Графік стану навчання нейронної мережі 


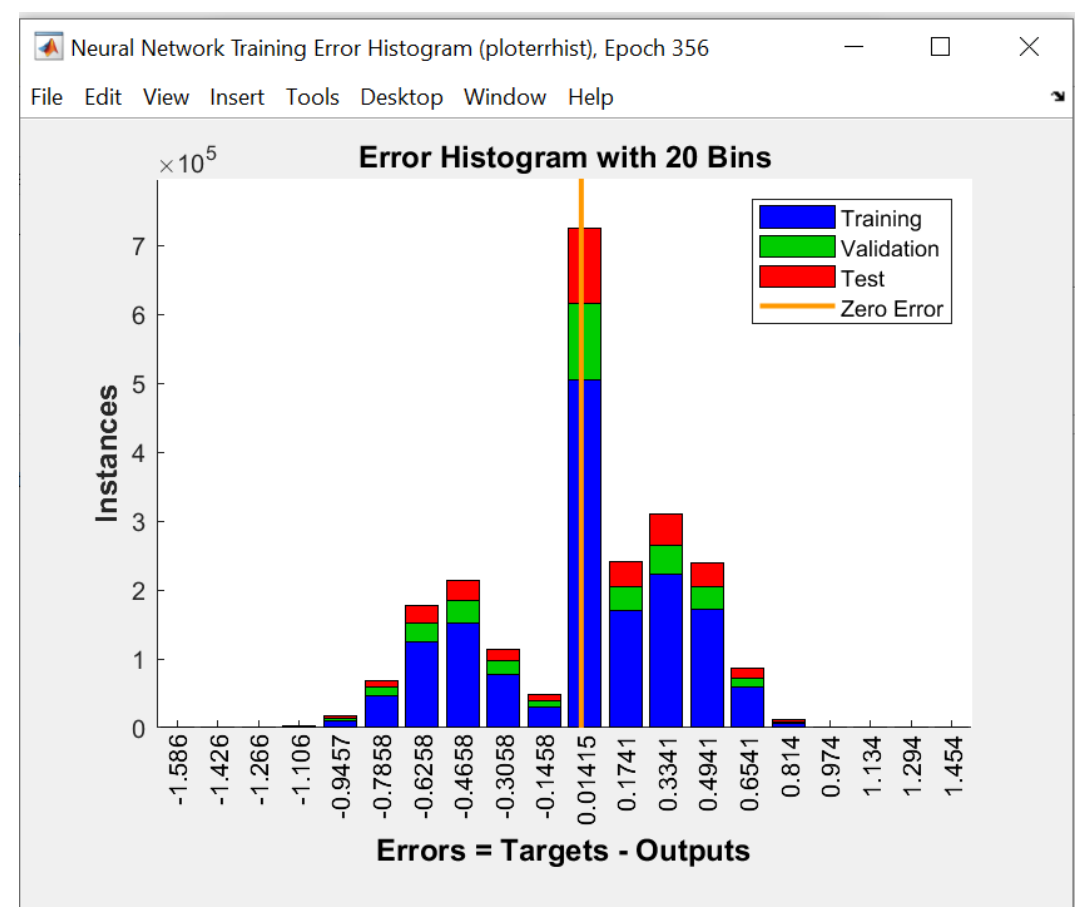

Рис. 15. Графік помилок

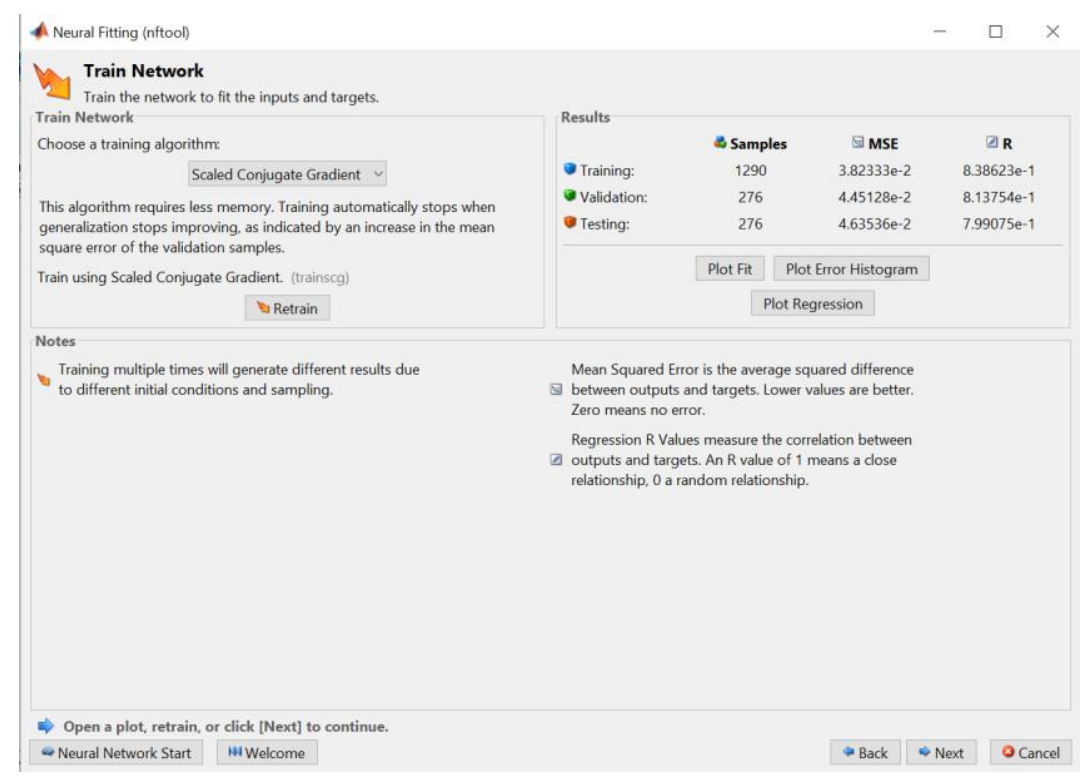

Рис. 16. Навчання нейронної мережі

\section{Висновки}

У статті досліджено методи спектрального аналізу зображень для детектування лісових пожеж 3 використанням технологій обчислювального інтелекту. Для проведення спектрального аналізу були використані супутникові знімки лісових пожеж з відкритих джерел NASA Earth Observatory. Для здійснення первинної обробки зображень було використано пакет MATLAB.

Для створення трьохвимірної моделі було використано інструмент Volume Segmenter в MATLAB. За допомогою даного інструменту було виділено трьохвимірну зону вогню на зображенні, що аналізується.

Для створення нейронної мережі з аналізу зображення розповсюдження вогню було використано метод спряжених градієнтів. Для навчання моделі було здійснено кілька проходів, щоб нейронна мережа показала максимально точні результати.

У подальших дослідженнях планується використати методи для фіксації інших небезпечних природних явищ, а також розробка рекомендацій щодо запобігання їх настання. Результати дослідження 
будуть використані для формування веб-сервісу у режимі реального часу, що буде фіксувати небезпечні природні явища, формувати сповіщення та надавати рекомендації для оперативної ліквідації їх наслідків.

\section{Список використаної літератури}

1. Battling Wildfire and Pandemic, Ukraine Faces a New Foe: Landmines. URL: https://www.nytimes.com/2020/10/03/world/europe/ukraine-wildfires-landmines.html (дата звернення 15.09.2021).

2. Bingsong He, Xueping Zhao, Zhiguo Zhou and Zheyi Fan. Implementation of a Fire Detection $\begin{array}{llll}\text { Algorithm on } & \text { TMS320DM642 using MATLAB/Simulink. URL: }\end{array}$ https://www.researchgate.net/publication/266646537_Implementation_of_a_Fire_Detection_Algorithm_on_TM S320DM642_DSP_using_MATLABSimulink (дата зверення 16.09.2021).

3. Turgay Celik. Fast and Efficient Method for Fire Detection Using Image Processing. URL: https://onlinelibrary.wiley.com/doi/pdf/10.4218/etrij.10.0109.0695 (дата звернення: 21.09.2021).

4. Журавль I.M. Короткий курс теорії обробки зображень. URL: https://hub.exponenta.ru/post/kratkiy-kurs-teorii-obrabotki-izobrazheniy734 (дата звернення: 15.09.2021).

5. Квєтний Р.Н., Богач І.В., Бойко О.Р., Софина О.Ю., Шушура О.М. Комп’ютерне моделювання систем та процесів. Методи обробки. Частина $2 . \quad$ URL: https://web.posibnyky.vntu.edu.ua/fksa/2kvetnyj_komp\%27yuterne_modelyuvannya_system_procesiv/t2/zm2..h tm (дата звернення: 15.09.2021).

6. Лобанов А.A. Геоінформаційний моніторинг пожеж. URL: https://cyberleninka.ru/article/n/geoinformatsionnyy-monitoring-pozharov/viewer (дата звернення: 01.10.2021).

7. Пітак І.В., Негадайлов А.А., Масікевич Ю.Г., Пляцук Л.Д., Шапорев В.П., Моісеєв В.Ф. Геоінформаційні технології в екології: Навчальний посібник. Чернівці, 2012.273 c. URL: https://geology.lnu.edu.ua/wp-content/uploads/2020/04/Ekolohichna-heoinformatyka_literatura-dlia-lektsiy.pdf (дата звернення: 01.10.2021).

\section{References}

1. Battling Wildfire and Pandemic, Ukraine Faces a New Foe: Landmines Available at: www.nytimes.com/2020/10/03/world/europe/ukraine-wildfires-landmines.html (accessed 15 September 2021).

2. Bingsong He, Xueping Zhao, Zhiguo Zhou and Zheyi Fan. Implementation of a Fire Detection Algorithm on TMS320DM642 DSP using MATLAB/Simulink. Available at: www.researchgate.net/publication/266646537_Implementation_of_a_Fire_Detection_Algorithm_on_TMS320D M642_DSP_using_MATLABSimulink (accessed 16 September 2021).

3. Turgay Celik. Fast and Efficient Method for Fire Detection Using Image Processing. Available at: www.onlinelibrary.wiley.com/doi/pdf/10.4218/etrij.10.0109.0695 (accessed 21 September 2021).

4. Zhuravl I.M. Korotkyi kurs teorii obrobky zobrazhen. Available at: www.hub.exponenta.ru/post/kratkiy-kurs-teorii-obrabotki-izobrazheniy734 (accessed 15 September 2021).

5. Kvietnyi R.N., Bohach I.V., Boiko O.R., Sofyna O.Iu., Shushura O.M. Kompiuterne modeliuvannia system ta protsesiv. Metody obrobky. Chastyna 2. Available at: www.web.posibnyky.vntu.edu.ua/fksa/2kvetnyj_komp\%27yuterne_modelyuvannya_system_procesiv/t2/zm2..ht $\mathrm{m}$ (accessed 15 September 2021).

6. Lobanov A.A. Heoinformatsiinyi monitorynh pozhezh. Available at: www.cyberleninka.ru/article/n/geoinformatsionnyy-monitoring-pozharov/viewer (accessed 01 October 2021).

7. Pitak I.V., Nehadailov A.A., Masikevych Yu.H., Pliatsuk L.D., Shaporev V.P., Moiseiev V.F. Heoinformatsiini tekhnolohii v ekolohii : Navchalnyi posibnyk. Chernivtsi, 2012. 273 s. Available at: www.geology.lnu.edu.ua/wp-content/uploads/2020/04/Ekolohichna-heoinformatyka_literatura-dlia-lektsiy.pdf (accessed 01 October 2021). 